course of oestrogen secretion in women during the menstrual cycle, the menopause, lactation, and endocrine ablative procedures. There is the possibility that there are unusual oestrogen metabolites peculiar to the pubertal period which were not detected, but this is thought to be unlikely.

The progressive increases in 17-keto and 17-ketogenic steroids with age correlate well with increasing maturity. The possibility that the gynaecomastia is due to a direct action of increased levels of androgen is unlikely, however, as the condition subsides with the attainment of maturity, when in fact an even higher level of androgen is being secreted.

We suggest that the most likely explanation for the occurrence of gynaecomastia at puberty is that the breast responds to enhanced levels of pituitary hormones, which are responsible for the anatomical and functional changes occurring at that time. The suggestion of Folley (1960), that growth hormone is the most likely active mammotrophic agent, is attractive in view of the fact that its action on the breast is often confined to the stimulation of duct growth, which is the predominant element in gynaecomastia, and that it might be expected to be present in higher concentrations at puberty, when there is an increased rate of body growth generally. The gynaecomastia subsides at the end of puberty, when pituitary activity has diminished.

Mammary hypertrophy may accompany the recovery of sexual potency when the diet is restored to normal after prolonged malnutrition (Klatskin, Salter, and Humm, 1947). This phenomenon may be a consequence of excessive pituitary activity following a period of inhibition and may be likened to a second puberty with the restimulation of testicular function. It would be of the greatest interest to know the steroid excretion of men during refeeding after chronic starvation. It might be expected that they would have intermediate values for $17-\mathrm{KS}$ excretion and low urinary oestrogen concentrations, similar to those found here for pubertal boys.

The local requirement for oestrogen in breast growth is minimal and probably present in all normal individuals of any age. Given this basic steroid environment, duct growth will follow an elevation of the concentration of growth hormone or prolactin. The concentration of oestrogen necessary to stimulate the secretion of prolactin by the pituitary is presumably above that found in normal men, but increase in oestrogen, either by changes in its secretion or by administration, may raise the level to that required.

The hormonal factors which we suggest are usually involved in the control of breast proliferation in the male may therefore be summarized as follows: (1) pre-pubertally the minimum of oestrogen necessary is present but there is insufficient pituitary stimulation and thus no outgrowth; (2) at puberty growthhormone secretion is increased, and, in the presence of the small concentrations of oestrogen already present, causes duct proliferation; (3) at maturity although the level of oestrogen secretion rises it does not reach a level at which prolactin secretion is stimulated-the secretion of growth hormone diminishes, and in the consequent absence of sufficient levels of pituitary hormones there is regression of any breast development ; and (4) with high levels of exogenous or endogenous oestrogen prolactin secretion is stimulated, causing marked mammary growth.

This hypothesis ascribes a functional role to the amount of oestrogen in the normal male.

\section{Summary}

The urinary excretion of oestriol, oestrone, oestradiol, 17-KS, 17-KGS, pregnanediol, and pregnanetriol was studied in prepubertal boys, pubertal boys with and without gynaecomastia, and post-pubertal boys.

The excretion of 17-KS and 17-KGS increased with increasing age and maturity. Oestrogen excretion, however, remained at a low level until full maturity was attained and gynaecomastia, where present, had regressed.

It is concluded that gynaecomastia of puberty is not associated with an increased concentration of oestrogens, but is associated with the increased secretion of pituitary hormones.

We wish to express our thanks to the headmaster and senior biology master and boys of the school, who went to considerable trouble to help us with this work.

\section{REPERENCES}

Brown, J. B., Bulbrook, R. D., and Greenwood, F. C. (1957). F. Endocr., 16,49

Drekter, I. J., Heisler, A., Scism, G. R., Stern, S., Pearson, S., and McGavack, T. H. (1952). F. clin. Endocr., 12, 55 .

Folley, S. J. (1960). Clin. Endocr., 1, 518.

Hall, P. F. (1959). Gynaecomastia. Australasian Medical Publishing Co., Sydney.

Jull, J. W., Shucksmith, H. S., and Bonser, G. M. (1963). F. clin. Endocr., 23, 433.

A. E., and Wade, A. P. (1957). Biochem. F. 66, 196

Klatskin, G., Salter, W. T., and Humm, F. D. (1947). Amer. J. med. Sci., 213, 19.

Leon, Y. A., and Bulbrook, R. D. (1960). F. Endocr., 20, 236.

Norymberski, J. K., Stubbs, R. D., and West, H. F. (1953). Lancet, 1,
1276 .

\title{
Hormone Excretion Studies of Males with Gynaecomastia
}

\author{
J. W. JULL,* PH.D., B.SC. (Leeds)； G. M. BONSER, † M.D., F.R.C.P. ; J. A. DOSSETT, $\ddagger$ M.D.
}

Brit. med. F., 1964, 2, 797-799

Gynaecomastia is encountered clinically in men either as a primary cause for complaint or as a symptom of some fundamental disturbance such as adrenal or testicular tumour. In

- Department of Experimental Pathology and Cancer Research, University of Leeds. Present address: Cancer Research Centre, University of British Columbia, Vancouver 8, Canada.

t Department of Experimental Pathology and Cancer Research, University of Leeds, and Department of Pathology, St. James's Hospital,

‡ Department of Pathology, St. James’s Hospital, Leeds. the preceding report (Jull and Dossett, 1964) evidence was presented that gynaecomastia of puberty was not associated with elevated oestrogen secretion. It was suggested that the cause of the condition is pituitary growth hormone.

From the considerable clinical evidence there can be little doubt that gynaecomastia may also be an accompaniment of conditions in which there is enhanced oestrogen secretion. The following investigations were undertaken to determine the urinary hormone excretion of men with gynaecomastia in an attempt to delineate the hormonal conditions responsible. 


\section{Methods}

Urine was collected for periods of at least three days from 11 normal mature males of various ages, 12 men with persistent gynaecomastia, and 3 men during the presence of gynaecomastia and after its regression.

The urine was pooled and stored at $-20^{\circ} \mathrm{C}$. until assayed for oestriol, oestrone, oestradiol, pregnanediol, pregnanetriol, 17-ketosteroids (17-KS), and 17-ketogenic steroids (17-KGS), as described by Jull and Dossett (1964).

\section{Results}

Table I shows the urinary excretion of hormone metabolites found for 11 normal men without gynaecomastia. With the exception of the level of $2.1 \mathrm{mg}$. of pregnanediol found for subject 20 , neither the amounts of pregnanediol nor the amounts of pregnanetriol are abnormal. The excretions of $17-\mathrm{KS}$ and 17-KGS are comparable with those commonly found for normal men. Total oestrogen excretion-that is, the sum of oestriol, oestrone, and oestradiol—ranged from 4.2 to $10.2 \mu \mathrm{g}$. daily.

TАВLв I.-Average Daily Excretion of Hormone Metabolites by Normal Men Without Gynaecomastia

\begin{tabular}{|c|c|c|c|c|c|c|c|c|c|}
\hline $\begin{array}{l}\text { Sub- } \\
\text { ject } \\
\text { No. }\end{array}$ & $\begin{array}{l}\text { Age } \\
\text { Years }\end{array}$ & $\begin{array}{c}\text { Oest- } \\
\text { triol } \\
\mu \mathrm{g} .\end{array}$ & $\begin{array}{c}\text { Oest- } \\
\text { rone } \\
\mu \mathrm{g} .\end{array}$ & $\begin{array}{c}\text { Oest- } \\
\text { radiol } \\
\mu \mathrm{g} .\end{array}$ & $\begin{array}{c}\text { Total } \\
\text { Oest- } \\
\text { rogen } \\
\mu \mathrm{g} .\end{array}$ & $\begin{array}{l}\text { Pregna- } \\
\text { nediol } \\
\text { mg. }\end{array}$ & $\begin{array}{l}\text { Pregna- } \\
\text { netriol } \\
\text { mg. }\end{array}$ & $\begin{array}{c}17-\mathrm{KS} \\
\mathrm{mg} .\end{array}$ & $\begin{array}{c}\text { KG- } \\
\text { mg. }\end{array}$ \\
\hline $\begin{array}{c}16 \\
17 \\
18 \\
19 \\
20\{ \\
21-26\end{array}$ & $\begin{array}{l}21 \\
34\end{array}$ & $\begin{array}{l}1.6 \\
4.2 \\
7.9 \\
2.7 \\
2.3 \\
0.9 \\
3.6\end{array}$ & $\begin{array}{l}4 \cdot 6 \\
6 \cdot 0 \\
2 \cdot 0 \\
5 \cdot 9 \\
4 \cdot 0 \\
2 \cdot 7 \\
2 \cdot 5\end{array}$ & $\begin{array}{l}2.5 \\
0.0 \\
0.0 \\
0.6 \\
2 \cdot 2 \\
0.6 \\
1 \cdot 4\end{array}$ & $\begin{array}{r}8 \cdot 7 \\
10 \cdot 2 \\
9 \cdot 9 \\
9 \cdot 2 \\
8 \cdot 5 \\
4 \cdot 2 \\
7 \cdot 5\end{array}$ & $\begin{array}{l}1.3 \\
1.8 \\
1.4 \\
1.4 \\
2.1 \\
0.6\end{array}$ & $\begin{array}{l}0.7 \\
0.8\end{array}$ & $\begin{array}{r}4 \cdot 1 \\
16 \cdot 1 \\
10 \cdot 1\end{array}$ & $\begin{array}{r}7.9 \\
8.9 \\
15 \cdot 0\end{array}$ \\
\hline
\end{tabular}

* Average readings of six subjects (Jull and Dossett, 1964).

The hormone-excretion data of 12 males whose only complaint was gynaecomastia are presented in Table II. The results are considered in groups which appear to subdivide them according to diagnosis. In assessing the significance of the urinary hormone concentrations it is essential to relate them to the other information obtained by physical examination.

Subjects 6 and 8 had oestrogen excretions within the normal adult male range. The $17-\mathrm{KS}$ excretion of subject 6 was above

TABLE II.-Average Daily Excretion of Hormone Metabolites by Males

\begin{tabular}{|c|c|c|c|c|c|c|c|c|c|}
\hline $\begin{array}{l}\text { Sub- } \\
\text { ject } \\
\text { No. }\end{array}$ & $\begin{array}{c}\text { Age } \\
\text { Years }\end{array}$ & $\begin{array}{l}\text { Oest- } \\
\text { riol } \\
\mu \mathrm{g} .\end{array}$ & $\begin{array}{c}\text { Oest- } \\
\text { rone } \\
\mu \mathrm{g} .\end{array}$ & $\begin{array}{l}\text { Oest- } \\
\text { radiol } \\
\mu \mathrm{g} .\end{array}$ & $\begin{array}{c}\text { Total } \\
\text { Oestro- } \\
\text { gens } \mu \mathrm{g} .\end{array}$ & $\begin{array}{c}\text { Pregna- } \\
\text { nediol } \\
\text { mg. }\end{array}$ & $\begin{array}{l}\text { Pregna- } \\
\text { netriol } \\
\text { mg. }\end{array}$ & $\begin{array}{l}17- \\
\mathrm{KS} \\
\mathrm{mg} .\end{array}$ & $\begin{array}{c}\text { 17- } \\
\text { mg. }\end{array}$ \\
\hline 1 & 6 & 1.4 & 0.7 & 0.0 & $2 \cdot 1$ & 0.2 & $0 \cdot 1$ & $1 \cdot 2$ & $7 \cdot 7$ \\
\hline 2 & 17 & $\left\{\begin{array}{l}2 \cdot 0 \\
1 \cdot 2\end{array}\right.$ & $\begin{array}{l}1.2 \\
0.9\end{array}$ & $\begin{array}{l}0.0 \\
0.0\end{array}$ & $\begin{array}{l}\begin{array}{l}3 \cdot 2 \\
2 \cdot 1\end{array} \\
2\end{array} 2 \cdot 6$ & - & 0.3 & $5 \cdot 1$ & $7 \cdot 6$ \\
\hline 3 & $\begin{array}{l}19 \\
85\end{array}$ & $\begin{array}{l}1.2 \\
3.5\end{array}$ & $\begin{array}{l}3 \cdot 2 \\
2.6\end{array}$ & $\begin{array}{l}0.0 \\
0.3\end{array}$ & $\begin{array}{r}4.4 \\
6.4\end{array}$ & $\begin{array}{l}1.3 \\
0.9\end{array}$ & 0.9 & $\begin{array}{l}8.9 \\
5.5\end{array}$ & 二 \\
\hline $\begin{array}{l}4 \\
5\end{array}$ & $\begin{array}{l}85 \\
30\end{array}$ & $\begin{array}{l}3.5 \\
2 \cdot 1\end{array}$ & $\begin{array}{l}2 \cdot 6 \\
3 \cdot 6\end{array}$ & $\begin{array}{l}0.3 \\
0.9\end{array}$ & $\begin{array}{l}0.4 \\
6.6\end{array}$ & $\begin{array}{l}0.9 \\
1 \cdot 2\end{array}$ & $\overline{1 \cdot 2}$ & $\begin{array}{r}5 \cdot 3 \\
12 \cdot 6\end{array}$ & $\overline{4 \cdot 7}$ \\
\hline 6 & 14 & $4 \cdot 7$ & 1.5 & $1 \cdot 7$ & $7 \cdot 9$ & - & -1 & 3.8 & \\
\hline 7 & 29 & $3 \cdot 3$ & 3.8 & 1.2 & $\begin{array}{l}8 \cdot 3 \\
8 \cdot 7\end{array}$ & 0.5 & $1 \cdot 2$ & 14.6 & $4 \cdot 6$ \\
\hline $\begin{array}{l}8 \\
9\end{array}$ & 14 & $\begin{array}{l}5 \cdot 5 \\
4.5\end{array}$ & $\begin{array}{l}1 \cdot 6 \\
2 \cdot 7\end{array}$ & $\begin{array}{l}1 \cdot 6 \\
2 \cdot 0\end{array}$ & $\begin{array}{l}8 \cdot 7 \\
9 \cdot 2\end{array}$ & $\overline{1.5}$ & $1 \cdot 1$ & $9 \cdot 5$ & $23 \cdot 8$ \\
\hline 10 & 64 & $8 \cdot 4$ & 1.6 & 0.0 & 10.0 & $1 \cdot 1$ & $0 \cdot \overline{3}$ & & - \\
\hline 11 & 56 & $11 \cdot 7$ & $2 \cdot 9$ & 0.0 & 14.6 & $0 . \overline{9}$ & 0.6 & 7.9 & - \\
\hline 12 & 20 & 10.5 & $5 \cdot 4$ & 1.5 & $17 \cdot 4$ & $1 \cdot 6$ & - & $8 \cdot 0$ & $12 \cdot 3$ \\
\hline
\end{tabular}

the pre-pubertal level. It seems likely from the data and their ages that both were in the final phase of puberty, with normal androgen secretion and oestrogen levels already risen to the post-pubertal level. No other abnormalities were found clinically, and the gynaecomastia regressed spontaneously in Subject 6 but was removed surgically from Subject 8 .

The total oestrogen excretion of Subjects 1,2 , and 3 was less than for normal mature men. Subjects 2 and 3 had 17-KS figures indicative of actively secreting testes, and this, together with the low oestrogen excretion, suggests that these were gynaecomastias of puberty. The ages of 17 and 19 years agree with a diagnosis of delayed puberty. It would oe expected that the gynaecomastia would regress spontanenusly with the attainment of complete testicular function. Subject 1 , aged 6 , was a thin child with no evidence of sexual precocity consistent with the low excretion of $17-\mathrm{KS}$. The oestrogen excretion was low, as in other pre-pubertal boys, and no suggestion can be made regarding the cause of the gynaecomastia. The lesion was unilateral, and was removed surgically because of its size.

Subjects 11 and 12 were excreting amounts of oestrogen at or above the normal upper limit, and this was probably the cause of their mammary hypertrophy. There was no other evidence of abnormal testicular or adrenal function, nor was there any significant alteration in the size of the breast over 12 months of observation.

No abnormality was found in the hormone excretion of Subjects $4,5,7,9$, or 10 and no cause of the gynaecomastia is apparent. Elevated oestrogen secretion does not appear to have been the cause. It is of interest that Subject 4 was 85 years old but nevertheless his urinary $17-\mathrm{KS}$ and oestrogen excretions were within the same limits as those of normal young men.

Subjects 13, 14, and 15 (Table III) are of special interest in that hormone estimations were made during the presence of gynaecomastia and after its regression. Subject 13 had high excretions of oestrogens and 17-KS coincident with the presence of a testicular tumour containing elements of chorioncarcinoma (Daly, Dossett, and Jull, 1963). Two weeks after removal of the affected testis the oestrogen excretion had fallen to a normal level of $7.1 \mu \mathrm{g}$., which was not significantly altered more than 16 months after the operation, when the gynaecomastia had completely regressed and there was no sign of recurrence of the testicular tumour. Subject 14 had gynaecomastia unassociated with any other abnormality and the urinary oestrogen excretion was initially high. The gynaecomastia subsequently regressed spontaneously, and at this time, eight months afterwards, oestrogen excretion was within normal limits.

Subjects 13 and 14 illustrate cases in which an initial high oestrogen excretion was associated with gynaecomastia, and subsequent reduction of the oestrogen excretion was accompanied by regression of the mammary hypertrophy. In subject 13 the fall in oestrogen was certainly associated with the moment of surgical removal of an oestrogen-secreting tumour. In Subject 14 the lowering of oestrogen excretion was not due to treatment and presumably followed a spontaneous change in secretion. Whatever the secretory mechanism involved in these

TABLE III.-Variations in Daily Excretion of Hormone Metabolites Associated with the Regression of Gynaecomastia

\begin{tabular}{|c|c|c|c|c|c|c|c|c|c|c|c|}
\hline $\begin{array}{l}\text { Subiect } \\
\text { No. }\end{array}$ & $\begin{array}{l}\text { Age } \\
\text { Years }\end{array}$ & $\begin{array}{l}\text { Day of } \\
\text { Investi- } \\
\text { gation }\end{array}$ & $\begin{array}{l}\text { Oestriol } \\
\mu \mathrm{g} .\end{array}$ & $\begin{array}{l}\text { Oestrone } \\
\mu \mathrm{g} .\end{array}$ & $\begin{array}{l}\text { Oestradiol } \\
\mu \mathrm{g} .\end{array}$ & $\begin{array}{c}\text { Total } \\
\text { Oestrogens } \\
\mu \mathrm{g} .\end{array}$ & $\underset{\text { mg. }}{\text { Pregnanediol }}$ & $\underset{\mathrm{mg} .}{\text { Pregnanetriol }}$ & $\begin{array}{l}\text { 17-KS } \\
\text { mg. }\end{array}$ & $\begin{array}{l}\text { 17-KGS } \\
\mathrm{mg} .\end{array}$ & $\begin{array}{c}\text { Gynae- } \\
\text { comastia }\end{array}$ \\
\hline \multirow{2}{*}{\multicolumn{12}{|c|}{\begin{tabular}{c|c}
32.7 & 3.0 \\
Testicular & tumour removed
\end{tabular}}} \\
\hline & & & & & & & & & & & \\
\hline 13 & 34 & $\begin{array}{c}21-24 \\
108-111 \\
493-496\end{array}$ & $\begin{array}{l}0 \cdot 0 \\
2 \cdot 2 \\
1 \cdot 8\end{array}$ & $\begin{array}{l}6 \cdot 0 \\
6 \cdot 3 \\
4 \cdot 9\end{array}$ & $\begin{array}{l}1 \cdot 1 \\
1 \cdot 4 \\
2 \cdot 0\end{array}$ & $\begin{array}{l}7 \cdot 1 \\
9 \cdot 9 \\
8 \cdot 7\end{array}$ & $\begin{array}{l}2 \cdot 8 \\
3 \cdot 4 \\
2 \cdot 6\end{array}$ & $\begin{array}{l}- \\
-\end{array}$ & $\begin{array}{l}\overline{4 \cdot 8} \\
4 \cdot 8\end{array}$ & $\overline{-}$ & $\begin{array}{l}--- \\
-\overline{-}\end{array}$ \\
\hline 14 & 42 & $\begin{array}{c}1-3 \\
6-9 \\
245-248\end{array}$ & $\begin{array}{r}13.1 \\
10.4 \\
3.4\end{array}$ & $\begin{array}{l}6 \cdot 8 \\
8 \cdot 5 \\
4 \cdot 2\end{array}$ & $\begin{array}{l}2 \cdot 0 \\
3 \cdot 2 \\
1 \cdot 2\end{array}$ & $\begin{array}{r}21 \cdot 9 \\
22 \cdot 1 \\
8 \cdot 8\end{array}$ & $\begin{array}{l}1 \cdot 1 \\
-\end{array}$ & $\bar{z}$ & $\begin{array}{l}8 \cdot 0 \\
-\end{array}$ & $\begin{array}{c}12 \cdot 3 \\
=\end{array}$ & $\begin{array}{l}+++ \\
+++ \\
---\end{array}$ \\
\hline 15 & 46\{ & $\begin{array}{c}1-3 \\
123-126\end{array}$ & $\begin{array}{l}0 \cdot 6 \\
4 \cdot 0\end{array}$ & $\begin{array}{l}2 \cdot 8 \\
3 \cdot 8\end{array}$ & $\begin{array}{l}0.0 \\
1.3\end{array}$ & $\begin{array}{l}3 \cdot 4 \\
9 \cdot 1\end{array}$ & $\begin{array}{l}0 \cdot 8 \\
1 \cdot 0\end{array}$ & $\overline{0.7}$ & $\begin{array}{l}6 \cdot 9 \\
-\end{array}$ & $\overline{-}$ & \pm++ \\
\hline
\end{tabular}


two cases, it is apparent that abnormally high oestrogen excretion and gynaecomastia were coincident and probably related.

Subject 15 , on the other hand, had a comparatively low oestrogen excretion during the presence of gynaecomastia, and this was increased to a value within the normal range after the condition had subsided. This case might be analogous to the gynaecomastias of puberty, where pituitary activity, uninhibited by the normal adult secretion of oestrogen, results in the release of hormones which stimulate mammary growth. Subsequent to recovery of oestrogen secretion to normal levels, the pituitary is once again controlled and the release of mammotrophic hormones is depressed.

\section{Discussion}

Of the 15 cases of gynaecomastia studied, three can be explained on the basis of abnormally low oestrogen production, two cases were probably due to pubertal increases in pituitary activity, and five were consequent upon increased oestrogen secretion. In the remaining five cases some other cause of the increased breast growth must be sought.

Breast growth in cases with excessive oestrogen excretion is not unexpected, nor is its regression following the reduction of oestrogen excretion to a normal level. It is perhaps surprising that only one-third of the cases investigated came into this category. In only one case was the excessive oestrogen shown to be due to a tumour, although this possibility is often first considered as an explanation for mammary hypertrophy in the adult male. Apparently (Subject 14) the endogenous oestrogen can vary over a sufficiently wide range that transient gynaecomastia may be observed. Such fluctuations in oestrogen production might well be related to variations in emotional or physical stress.

In the absence of methods for the estimation of pituitary secretion it is difficult to exend knowledge of the circumstances in which gynaecomastia may occur. Non-endocrine aetiological factors are important, but the nature of these is at present obscure. It should be accepted, however, that adult male mammary growth may be due to a number of fundamentally different reasons. Oestrogen excess is the least common of these, but, on account of its possible association with neoplasia, the one most desirable to exclude.

\section{Summary}

The urinary excretion of oestriol, oestrone, oestradi,l, pregnanediol, pregnanetriol, $17-\mathrm{KS}$, and $17-\mathrm{KGS}$ is reported for 11 normal men and 15 males with gynaecomastia.

Abnormally high oestrogen excretion was found in five of the patients with gynaecomastia. Three patients were excreting less oestrogen than is normal. In the remaining seven patients oestrogen excretion was within the normal range.

In two patients regression of mammary hypertrophy was associated with reduction of an unusually high oestrogen excretion, while in one other patient regression was accompanied bv increase in oestrogen excretion to normal from a subnormal level.

\section{REFERENCES} Daly, D. W., Dossett, J. A., and Jull, J. W. (1963). Brit. F. Surg., St,

Jull, J. W., and Dossett, J. A. (1964). Brit. med. F., 2, 795.

\title{
Anterior Radiculopathy and Lupus Erythematosus Cells : Report of Case*
}

\author{
GUY GARGOUR,† M.D. ; KEITH MACGAFFEY, $\ddagger$ M.D. ; SIMEON LOCKE,§ M.D. ; MAX D. STEIN,\| M.D.
}

[With Special Plate]

Brit. med. F., 1964, 2, 799-801

Collagen diseases as a group and systemic lupus erythematosus in particular are receiving increasing attention as their protean manifestations become more familiar. Affection of the nervous system in lupus erythematosus has been reported. In particular, Heptinstall and Sowry (1952), Siekert and Clark (1955), and Scheinberg (1956) have presented cases of involvement of peripheral nerves early in the course of the disease. The current case is unique in that findings of an anterior radiculopathy in the presence of positive lupus erythematosus preparations and positive serum fluorescent antibody reactions occurred in the absence of any of the known constitutional manifestations of systemic lupus.

\section{Case Report}

A 32-year-old white married woman was admitted to hospital in April 1963 with a chief complaint of progressive weakness and aching of her limbs. She had been in good health until April 1959, when, following the delivery of her third child, leg cramps, initially attributed to pregnancy, persisted for a period of six months. In
1959 she was involved in a minor car accident and sustained "whiplash" injury. From that time she experienced occipital, suboccipital, and neck pain. Accompanying these she noted progres. sive weakness of her legs and "heaviness" of her body. One vear prior to admission her grasp became weak. She had episousic blurring of vision associated with mild discomfort in the right eye. Ophthalmological examination revealed no abnormality. Persistent fatigability, lack of energy, and increased desire for warmth appeared.

In July 1962, because of persistence of headache and weakness of the legs, she was admitted to ancther hospital, where bilateral carotid and bilateral vertebral angiograms were performed because of papilloedema. These studies revealed no abnormality. Lumbar puncture disclosed fluid under "increased pressure" with a protein

* From the Department of Medicine, New England Deaconess Hospital,

Boston, Mass., U.S.A.
t Medical Resident, New England Deaconess Hospital, Boston, Mass., U.S.A. ₹ Chief Resident in Medicine, New England Deaconess Hospital, Boston,
Mass., U.S.A. \$Neurologist, New England Deaconess Hospital, Boston, Mass., U.S.A.
|| Physician, Quincy City Hospital, Quincy, Mass, U.S.A. 